\title{
Pengaruh kemandirian daerah, kinerja pemerintah daerah, dan sistem pengendalian intern terhadap akuntabilitas pelaporan keuangan
}

\author{
Matilde Agnes Oktaviani ${ }^{1}$ Dian Purnama Sari ${ }^{2}$ \\ ${ }^{1,2}$ Pascasarjana Akuntansi, Universitas Katolik Widya Mandala Surabaya \\ *Email korespondensi: agnesoktaviani10@gmail.com
}

\begin{abstract}
Accountability of local goverment's financial reports is very important in the process to managing regional financial. Financial accountability is manifested in the form of financial statement, which have been audited by an independent organization, The Audit Board of Republic Indonesia (BPK RI), which is responsible for auditing the fairness of financial statement and providing audit opinions to determine the level of accountability of regional financial reports. The responsibility of the government to explain to stakeholders about financial information through financial statement must be run with the principle of accountability, it aims for goverment to get public trust. So that the goverment can prosper the community to regional development. This study aim to empirically examine the effect of regional independence, government performance, and internal control system on financial reporting accountability. Accountability of financial reporting is measured by audit opinion. The population was all local government at province of East Java. The sample are 38 districts/cities in 2015-2018 and sampling tecnique using purposive sampling. In this study the data collection uses secondary data documentation method in the form of local government financial statement and data analysis using logistic regression with SPSS 23. The result show that regional independence and government performance have significant impact to financial reporting accountability, while internal control system has no significant impact to financial reporting accountability.
\end{abstract}

Keyword: accountability, regional independence, government performance, internal control system

Saran sitasi: Oktaviani, M. A., \& Sari, D. P. (2020). Pengaruh kemandirian daerah, kinerja pemerintah daerah, dan sistem pengendalian intern terhadap akuntabilitas pelaporan keuangan. Jurnal Akuntansi dan Pajak, 21 (1), 186-193. doi: http://dx.doi.org/10.29040/jap.v21i1.1147

\section{DOI: http://dx.doi.org/10.29040/jap.v21i1.1147}

\section{PENDAHULUAN}

Pengelolaan keuangan negara adalah tanggung jawab pemerintah untuk kesejahteraan masyarakat yang diharapkan dapat meningkat. Namun pada kenyataannya terjadi penyalahgunaan dana yang bertujuan untuk memberikan keuntungan pada beberapa pihak tertentu yang memiliki wewenang dalam mengelola dan mempertanggungjawabkan penggunaan dana kepada publik. Penyalahgunaan tanggung jawab tersebut memberikan dampak yang buruk pada kondisi keuangan, dan pelayanan pemerintah kepada masyarakat menjadi tidak stabil. Upaya pemerintah untuk melakukan pemerataan dan pencapaian tujuan pengelolaan keuangan adalah memberikan kebijakan kepada pemerintah daerah untuk menjalankan urusan pemerintahan secara efektif agar tercapainya pemerataan disetiap daerah, sehingga seluruh kegiatan pemerintahan dapat dipertanggungjawabkan sebagai bentuk pelaksanaan otonomi daerah dengan berlandaskan prinsip akuntabilitas. Akuntabilitas adalah pertanggung jelasan bahwa organisasi atau pemerintah daerah harus mampu memberikan penjelasan atas aktivitas atau penggunaan dana publik. Pertanggungjelasan tersebut bertujuan untuk pemeriksaan dan evaluasi terhadap pemerintah daerah oleh pihak-pihak yang memiliki kewenangan secara politik (Wicaksono, 2015).

Berdasarkan teori keagenan konflik kepentingan berkaitan erat dengan isu mengenai pemenuhan informasi dan asimetri informasi, yang berarti salah satu pihak principal dan agent memiliki lebih banyak informasi (umumnya agent) yang menyebabkan asimetri informasi sehingga keadaan ini menempatkan pihak lain kekurangan informasi (Bastian, 2006: 314). Untuk mengurangi konflik 


\section{Jurnal Akuntansi dan Pajak, 21 (01), 2020, 187}

kepentingan atau asimetri informasi, Badan Pemeriksa Keuangan (BPK) sebagai pihak independen mengaudit laporan keuangan untuk melakukan proksi bahwa pemerintah daerah menerapkan akuntabilitas keuangan secara keseluruhan melalui penilaian kewajaran informasi. Oleh karena itu BPK memberikan opini audit sebagai penilaian atas akuntabilitas laporan keuangan (Afriyanti dkk, 2015). Semakin baik opini pemda semakin tinggi tingkat akuntabilitas pelaporan keuangan. Peningkatan akuntabilitas keuangan daerah adalah upaya yang dijalankan pemerintah daerah tanpa campur tangan pemerintah pusat melalui penyajian laporan keuangan (Suryanto, 2017). Hal ini berarti daerah dapat secara mandiri mampu meningkatkan akuntabilitas. Penelitian Fontanella dan Rossieta (2014), Erryana dan Setyawan (2016), Mudhofar dan Tahar (2016) memberikan hasil yaitu kemandirian daerah memiliki pengaruh positif terhadap akuntabilitas pelaporan keuangan yang bermakna jika tingkat kemandirian daerah tinggi maka akuntabilitas pelaporan keuangan daerah tersebut akan meningkat, sedangkan penelitian Irmawati dan Pratolo (2016) menemukan bahwa kemandirian daerah tidak memiliki pengaruh terhadap akuntabilitas pelaporan keuangan daerah.

Pencapaian keberhasilan dalam penerapan otonomi daerah didukung oleh kinerja pemerintah yang dijalankan secara tertib dan bertanggung jawab dalam pengelolaan keuangan (Lazyra,2016). Penelitian Fontanella dan Rossieta (2014) dan Irmawati dan Pratolo (2016) menemukan bahwa akuntabilitas pelaporan keuangan daerah akan meningkat jika kinerja pemerintah daerah juga meningkat, yang berarti kinerja pemerintah memiliki pengaruh yang positif terhadap akunntabilitas pelaporan keuangan sedangkan dalam penelitian Purbasari dan Bawono (2017) kinerja keuangan tidak memiliki pengaruh terhadap akuntabilitas pelaporan keuangan. Pemerintah daerah dapat mempertanggungjawabkan realisasi dari anggaran yang telah ditargetkan sebagai proksi bahwa pemerintah daerah mampu menghasilkan pendapatan dengan menggunakan sumber daya yang ada termasuk pengelolaan aset yang baik dan benar. BPK menemukan beberapa kasus audit bahwa pemerintah daerah belum dapat mengelola aset dengan jelas yang berdampak pada pengakuan aset yang tidak sesuai, sehingga akan memengaruhi opini audit dan akuntabilitas laporan keuangan pemda menurun.
Ikhtisar Hasil Pemeriksaan Semeser I (IHPS) tahun 2019 menyajikan data bahwa beberapa pemerintah daerah memiliki penurunan opini audit. Pada provinsi Jawa Timur terdapat 3 kabupaten/kota mengalami penurunan opini dari WTP menjadi WDP, 2 diantaranya yaitu kota Pasuruan dan kabupaten Jember yang memiliki permasalahan aset tetap dan aset lancar. Oleh karena itu, untuk meningkatkan kinerjanya pemerintah tidak hanya berfokus pada pencapaian antara realisasi pendapatan dan target pendapatan tetapi pemerintah perlu memperhatikan pengelolaan aset sebagai sumber daya untuk memperoleh pendapatan sehingga dapat meningkatkan akuntabilitas pemda dalam mencapai tujuan sebagai daerah otonom.

Tanggung jawab pemerintah daerah untuk mencapai tujuan dalam mensejahterakan masyarakat tidak hanya berfokus pada pelaporan penggunaan dana publik kepada pihak eksternal tetapi perlu diimbangi dengan pengendalian internal. Pengendalian merupakan satu dimensi dalam akuntabilitas, yang merujuk pada suatu organisasi melakukan secara tepat apa yang menjadi perintah utama (Aman dkk, 2013). Penelitian Asfiryati (2017) menemukan bahwa akuntabilitas pelaporan keuangan daerah akan terlaksana jika sistem pengendalian intern berjalan sesuai dengan kebijakan yang telah ditetapkan yang berarti sistem pengendalian intern memilki pengaruh positif terhadap akuntabilitas pelaporan keuangan. Penelitian Santoso (2016) SPI tidak memiliki pengaruh terhadap akuntabilitas keuangan. Pada tahun 2018 hasil pemeriksaan BPK terhadap LKPD ditemukan 5858 kelemahan SPI. Perbaikan atas temuan terkait kelemahan SPI disampaikan dalam bentuk rekomendasi oleh BPK (Essing dkk, 2017). Salah satu indikator akuntabilitas pemerintah daerah adalah seberapa aktif pemerintah daerah menindaklanjuti rekomendasi hasil pemeriksaan BPK (BPK RI, 2018). Dengan adanya tindak lanjut rekomendasi yang sesuai, maka opini pemerintah daerah akan lebih baik (Pratiwi dan Aryani, 2016). Jika pemerintah daerah melakukan tindak lanjut untuk memperbaiki temuan kelemahan SPI yang sesuai dengan rekomendasi BPK, maka SPI akan semakin baik sehingga akuntabilitas pelaporan keuangan pemerintah daerah semakin meningkat.

Berdasarkan uraian diatas maka rumusan masalah dalam penelitian adalah apakah kemandirian daerah, kinerja pemerintah daerah dan sistem pengendalian intern berpengaruh terhadap 


\section{Jurnal Akuntansi dan Pajak, 21 (01), 2020, 188}

akuntabilitas pelaporan keuangan. Tujuan penelitian untuk mengetahui secara empiris pengaruh kemandirian daerah, kinerja pemerintah daerah dan sistem pengendalian intern berpengaruh terhadap akuntabilitas pelaporan keuangan sehingga dapat bermanfaat bagi pengguna laporan keuangan khususnya pemerintah daerah untuk selalu meningkatkan akuntabilitas pelaporan keuangan dengan memberikan informasi yang jelas kepada pemangku kepentingan.

\section{Teori keagenan}

Hubungan antara principal dan agent dalam organisasi pemerintahan yaitu rakyat sebagai principal yang diwakili oleh DPRD, mempercayakan pengelolaan kekayaan daerah kepada pemerintah daerah sebagai agent yang bertugas mengelola dana principal (Halim, 2007: 124), sebagai agent kepemilikan informasi pemerintah daerah lebih banyak terkait pengelolaan keuangan daerah dibandingkan dengan rakyat sebagai principal. Kejelasan informasi yang diberikan ke publik dapat berupa pelaporan terkait penggunaan dan realisasi anggaran baik untuk belanja urusan pemerintahan, maupun pengelolaan aset sebagai kekayaan daerah, melalui laporan keuangan. Pelaporan ini merupakan bentuk pertanggungjawaban pemerintah daerah dalam mengelola anggaran publik untuk mengatasi konflik keagenan. Laporan keuangan disajikan untuk menciptakan akuntabilitas pemerintah sebagai organisasi sektor publik.

\section{Akuntabilitas}

\section{Standar Akuntansi Pemerintah (SAP)} menyebutkan bahwa salah satu peranan pelaporan keuangan adalah untuk kepentingan akuntabilitas, yaitu pertanggungjawaban terkait pengelolaan sumber daya serta pelaksanaan kebijakan kepada entitas pelaporan yang dipercayakan untuk mencapai tujuan secara periodik. Akuntabilitas tidak hanya memastikan bahwa kebijakan sudah diterapkan sebagaimana mestinya tetapi organisasi publik harus mampu memberikan jawaban atau respon kepada pemangku kepentingan atas tindakan yang telah dilakukan (Peters, 2014). Jawaban tersebut berupa informasi yang disampaikan melalui laporan keuangan yang dapat digunakan oleh pemangku kepentingan dalam hal ini pemerintah pusat maupun DPRD sebagi wakil rakyat untuk pengambilan keputusan. akuntabilitas pelaporan keuangan dapat diartikan sebagai pertanggungjelasan pemerintah kepada publik bahwa keuangan pemerintah dikelola dengan tanggung jawab untuk mencapai tujuan meningkatkan kesejahteraan masyarakat dengan memberikan informasi atau jawaban yang jelas kepada publik terkait aktivitas pemerintah yang diwujudkan melalui laporan keuangan.

\section{Kemandirian daerah}

Pendanaan pemerintah daerah untuk mengelola daerahnya sendiri diperoleh dari PAD dan pendapatan transfer. Daerah dikatakan mandiri jika penggunaan PAD dalam pembangunan daerah lebih besar dibandingkan dengan penggunaan dana transfer (Jatmiko, 2016). PAD diperoleh dari pajak maupun retribusi daerah yang dibayarkan ke pemerintah untuk menambah kekayaan daerah atau negara dan digunakan sebagai sumber pembiayaan daerah. Dana transfer dari pemerintah pusat diakui sebagai pendapatan karena merupakan sumber pendanaan pemerintah daerah. Penerimaan pendapatan transfer dalam jumlah yang besar adalah dana alokasi umum (DAU). kemandirian daerah dapat disimpulkan sebagai rasio keuangan pemerintah yang diukur berdasarkan perbandingan antara realisasi pendapatan dengan DAU ditambah pinjaman, namun Utang Pajak Pusat (UPP) dan utang Perhitungan Fihak Ketiga (PFK) dikeluarkan karena bukan merupakan sumber pendapatan (Hadi, 2017), sehingga daerah secara mandiri akan selalu berusaha untuk meningkatkan akuntabilitas agar mendapat kepercayaan publik.

\section{Kinerja pemerintah}

Kinerja dapat didefinisikan sebagai pencapaian hasil kerja dari pelaksanaan suatu kegiatan untuk mencapai sasaran tujuan, visi dan misi organisai (Sujarweni, 2015:107). Kinerja terdiri dari kinerja keuangan dan non-keuangan. Penilaian kinerja keuangan daerah menggunakan indikator keuangan berdasarkan tingkat pencapaian hasil kerja yang bertujuan untuk mengetahui kemampuan mengelola keuangan suatu daerah (Pramita, 2015). Menurut Sujarweni (2015:107) beberapa tujuan dilakukannya pengukuran kinerja yaitu, mewujudkan tanggung jawab publik, mengalokasikan sumber daya, dan mendorong terciptanya akuntabilitas publik. Oleh karena itu pemerintah daerah dapat mempertanggungjawabkan realisasi dari anggaran yang telah ditargetkan untuk mengukur kemampuan pemerintah daerah sejauh mana pemda dapat 


\section{Jurnal Akuntansi dan Pajak, 21 (01), 2020, 189}

menghasilkan pendapatan dengan menggunakan sumber daya yang tersedia, yaitu aset yang dimiliki oleh pemerintah.

\section{Sistem pengendalian intern}

Sistem Pengendalian Intern (SPI) menurut Peraturan Pemerintah No. 60 tahun 2008 didefinisikan sebagai proses integral pada tindakan dan kegiatan yang dilakukan secara terus menerus oleh pemimpin dan seluruh pegawai untuk memberikan keyakinan memadai atas tercapainya tujuan organisasi melalui kegiatan yang efektif dan efisien, keandalan pelaporan keuangan, pengamanan aset negara, dan ketaatan terhadap peraturan perundangan-undangan. Nugoeira dan Jorge (2017) mengatakan bahwa tujuan utama dari pengendalian adalah untuk memastikan entitas melakukan kegiatan secara tertib dan efisien, transaksi berlangsung sesuai prosedur, kesalahan dapat dideteksi dan mampu menyiapkan informasi keuangan yang dihasilkan dalam laporan keuangan untuk memenuhi kewajiban akuntabilitas publik.

\section{Hipotesis penelitian}

\section{Pengaruh kemandirian daerah terhadap akuntabilitas pelaporan keuangan}

Daerah yang mandiri akan selalu berusaha untuk meningkatkan akuntabilitas agar mendapat kepercayaan publik sebagai pengelola keuangan daerah yang dapat berupa usaha untuk membangun daerah dengan melakukan kegiatan yang manfaatnya dapat dirasakan oleh masyarakat secara langsung. Jika pemda memiliki sumber pendanaan yang dapat membiayai pembangunan daerah secara mandiri, baik dari pendapatan maupun utang maka pemerintah daerah dapat meningkatkan akuntabilitas pelaporan keuangan karena pemerintah daerah secara mandiri mampu melakukan pembangunan daerah dengan berbagai kegiatan untuk kepentingan publik yang manfaatnya dapat dirasakan oleh masyarakat sehingga mendapatkan kepercayaan dari publik

Kepercayaan publik terhadap pemerintah memberi makna bahwa informasi keuangan yang disampaikan adalah informasi yang jelas dan akurat sesuai dengan harapan publik sehingga tanggung jawab pemda untuk melaporkan informasi penggunaan dana dalam laporan keuangan kepada publik semakin besar agar tujuan otonomi daerah tercapai. Maka hipotesis pertama yaitu:
H1: Kemandirian daerah berpengaruh positif terhadap akuntabilitas pelaporan keuangan daerah.

\section{Pengaruh kinerja pemerintah daerah terhadap akuntabilitas pelaporan keuangan}

Pelaporan keuangan pemerintah membahas tentang proses pengelolaan keuangan publik yang diwujudkan dalam bentuk laporan keuangan yang dapat dijadikan sumber informasi mengenai kinerja pemerintah yang memberikan pertanggungjawaban terhadap semua biaya yang dikeluarkan untuk memperoleh pendapatan yang digunakan untuk membangun daerah, oleh karena itu, peningkatan kinerja pemerintah daerah akan berdampak pada peningkatan akuntabilitas pelaporan keuangan (Irmawati dan Pratolo, 2016). Jika kinerja pemerintah daerah meningkat akan memberikan kepercayaan kepada publik bahwa informasi dalam laporan keuangan menunjukan keuangan daerah dikelola dengan penuh tanggung jawab untuk mencapai kesejahteraan masyarakat dan pemerintahan yang sedang berjalan diterima baik oleh masyarakat dalam hal membangun daerah yang sesuai dengan harapan publik sehingga terus berupaya meningkatkan akuntabilitas pelaporan keuangan. Maka hipotesis yang kedua yaitu:

H2: Kinerja pemerintah daerah berpengaruh positif terhadap akuntabilitas pelaporan keuangan.

\section{Pengaruh sistem pengendalian intern terhadap akuntabilitas pelaporan keuangan}

Nugoeira dan Jorge (2017) mengatakan bahwa tujuan utama dari pengendalian adalah untuk memastikan entitas melakukan kegiatan secara tertib dan efisien, transaksi berlangsung sesuai prosedur, kesalahan dapat dideteksi dan mampu menyiapkan informasi keuangan yang dihasilkan dalam laporan keuangan untuk memenuhi kewajiban akuntabilitas publik. Oleh karena itu, jika sistem pengendalian internal berjalan dengan baik maka akuntabilitas akan terlaksana (Asfiryati,2017), karena adanya pengendalian internal membantu pelaksanaan aktivitas pemerintah akan menjadi lebih efektif ketika melakukan pembangunan daerah sehingga dapat mengantisipasi berbagai risiko yang dapat menghambat proses untuk mencapai tujuan daerah dalam mensejahterakan masyarakat. Maka hipotesis yang ketiga yaitu: 


\section{Jurnal Akuntansi dan Pajak, 21 (01), 2020, 190}

H3: Sistem pengendalian berpengaruh positif terhadap akuntabilitas pelaporan keuangan.

\section{Rerangka Konseptual}

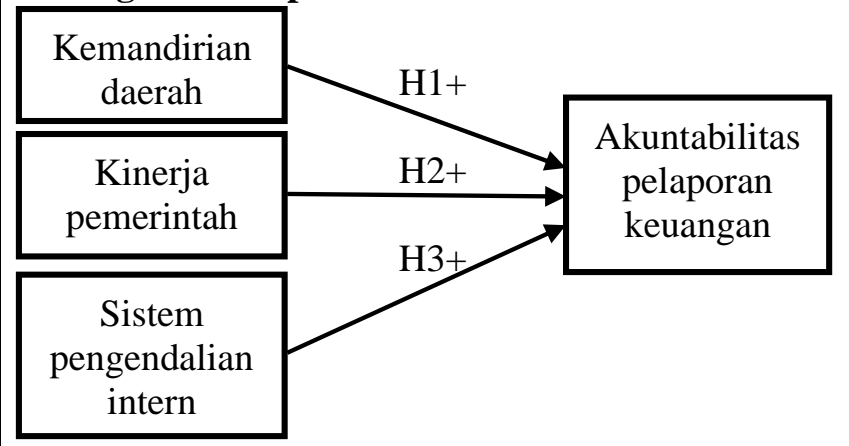

Gambar 2.1 Rerangka konseptual

\section{METODE PENELITIAN}

Pada penelitian ini dilakukan pengujian hubungan sebab akibat antar variabel dependen dan independen dengan penggunaan metode analisis kuantitatif untuk menguji hipotesis. Metode yang digunakan untuk pengumpulan data adalah metode dokumentasi berupa Laporan Keuangan Pemerintah Daerah (LKPD) seluruh kabupaten/kota di provinsi Jawa Timur tahun 2015-2018 dan IHPS I tahun 2019 BPK RI. Semua kabupaten/kota di provinsi Jawa Timur yang terdiri dari 29 kabupaten dan 9 kota untuk tahun anggaran 2015-2018 adalah populasi yang diambil untuk penelitian dengan teknik pengambilan sampel menggunakan cara purposive sampling, yaitu mengambil sampel dengan pertimbangan tertentu (Irmawati dan Pratolo, 2016). Kriteria pengambilan sampel adalah kabupaten/kota memiliki data lengkap yang meliputi LRA dan Neraca, opini audit yang tersedia pada IHPS I 2019 dan laporan Tindak Lanjut Rekomendasi Hasil Pemeriksaan (TLRHP) BPK untuk tahun anggaran 2015-2018. Regresi logistik biner digunakan dalam penelitian ini untuk menguji variabel dependen menggunakan pengukuran dummy dengan proses pengolahan data menggunakan software SPSS. Pengukuran variabel dependen dan variabel independen adalah sebagai berikut:

a. Akuntabilitas pelaporan keuangan adalah pertanggungjelasan pemerintah kepada publik bahwa keuangan pemerintah dikelola dengan tanggung jawab untuk mencapai tujuan meningkatkan kesejahteraan masyarakat dengan memberikan informasi atau jawaban yang jelas kepada publik terkait aktivitas pemerintah yang diwujudkan melalui laporan keuangan. Akuntabilitas pelaporan keuangan diukur menggunakan opini audit menggunakan variabel dummy yaitu diberi nilai 1 untuk pemerintah daerah yang memperoleh opini WTP dan diberi nilai 0 untuk pemerintah daerah yang tidak memperoleh opini WTP (Safitri dan Darsono, 2015).

b. PP No. 71 Tahun 2010 tentang Standar Akuntansi Pemerintah mencantumkan bahwa kemandirian entitas berarti setiap organisasi dianggap sebagai unit yang mandiri dan mempunyai kewajiban untuk menyajikan laporan keuangan agar tidak terjadi kekacauan antara unit instansi pemerintah dalam pelaporan keuangan. Pendanaan pemerintah daerah untuk mengelola daerahnya sendiri diperoleh dari PAD dan pendapatan transfer. Pendanaan pemerintah daerah untuk mengelola daerahnya sendiri diperoleh dari PAD dan pendapatan transfer. Daerah dikatakan mandiri jika penggunaan PAD dalam pembangunan daerah lebih besar dibandingkan dengan penggunaan dana transfer dari pemerintah pusat (Jatmiko, 2016).

Kemandirian daerah $=\frac{\text { Pendapatan Asli Daerah }(\text { PAD })}{(\text { DAU }+(\text { Utang-Utang PFK-Utang Pajak Pusat }))}$

c. Dalam penelitian ini kinerja keuangan dihitung menggunakan earning performance, yaitu rasio untuk menilai seberapa besar tingkat pendapatan per aset yang digunakan dalam mengolah sumber daya yang dimiliki untuk memperoleh pendapatan (Hadi, 2017).

$$
\text { Kinerja pemerintah }=\frac{\text { Surplus }(\text { Pendapatan }- \text { Belanja) }}{\text { Rata-rata total aset }}
$$

d. Berdasarkan PP No 60 Tahun 2008 tentang Sistem Pengendalian Intern Pemerintah (SPIP), menyebutkan bahwa salah satu unsur SPIP adalah unsur pemantauan yang dilaksanakan melalui pemantuan berkelanjutan, evaluasi terpisah, dan tindak lanjut rekomendasi hasil audit dan reviu lainnya.

Sistem Pengendalian Intern $=\frac{\text { Tindak lanjut rekomendasi sesuai }}{\text { Total rekomendasi }}$

Persamaan regresi logistiknya adalah sebagai berikut:

$\operatorname{Ln} \frac{\mathrm{AP}}{1-\mathrm{AP}}=\alpha 0+\beta_{1} \mathrm{KD}+\beta_{2} \mathrm{KP}+\beta_{3} \mathrm{SP}+\mathrm{e}$

Ket:

AP = Akuntabilitas Pelaporan

$\alpha \quad=$ Konstanta

$\beta=$ Koefisien Regresi

$\mathrm{KD}=$ Kemandirian Daerah

$\mathrm{KP}=$ Kinerja Pemerintah

SP $=$ Sistem Pengendalian Intern

e $\quad=$ Error 
Jurnal Akuntansi dan Pajak, 21 (01), 2020, 191

\section{HASIL DAN PEMBAHASAN}

Berikut ini merupakan hasil perolehan opini audit dari pengolahan sampel yang digunakan sebanyak 38 daerah pada provinsi Jawa Timur.

Tabel 4.1

Perolehan Opini Audit Tahun 2015-2018

\begin{tabular}{|c|c|c|c|c|c|}
\hline \multirow{2}{*}{ Tahun } & \multicolumn{5}{|c|}{ Opini } \\
\cline { 2 - 6 } & WTP & $\%$ & $\begin{array}{c}\text { Non } \\
\text { WTP }\end{array}$ & $\%$ & Jumlah \\
\hline 2015 & 28 & 73,7 & 10 & 26,3 & 38 \\
\hline 2016 & 30 & 78,9 & 8 & 21,1 & 38 \\
\hline 2017 & 36 & 94,7 & 2 & 5,3 & 38 \\
\hline 2018 & 35 & 92,1 & 3 & 7,9 & 38 \\
\hline Jumlah & 128 & 84,2 & 24 & 15,8 & 152 \\
\hline
\end{tabular}

Sumber: Data diolah

\section{Pengujian Keseluruhan Model Fit}

Dari hasil pengujian ini nilai -2 Log likelihood mengalami penurunan dari block 0 ke block 1 , kemudian dibandingkan dengan nilai pada tabel Chisquare dengan $\mathrm{df}=150(154-3-1 / \mathrm{N}$ - variabel dependen - 1). Pada df 150 dan probabilitas 0,05 nilai tabel Chisquare adalah 179,580634 sedangkan nilai 2 Log likelihood adalah 118,271 berarti 118,271< 179,580634 , yang bermakna bahwa model fit dengan data.

Tabel 4.2

Uji Nilai -2 Likelihood L

\begin{tabular}{|l|r|}
\hline \multicolumn{1}{|c|}{ Iteration } & -2Log likelihood \\
\hline Block 0 & 132.593 \\
\hline Block 1 & 118.271 \\
\hline
\end{tabular}

Sumber: Data diolah

\section{Pengujian Kelayakan Model Regresi}

Hasil pengujian Hosmer and Lemeshow's Goodness of fit ditunjukan pada tabel 4.3. Dari pengujian ini model regresi layak digunakan karena nilai signifikan sebesar 0,468 atau $46,8 \%$ yang artinya lebih dari 0,05 .

Tabel 4.3

Uji Hosmer and Lemeshow

\begin{tabular}{|c|c|c|c|}
\hline Step & Chi-square & $d f$ & Sig. \\
\hline 1 & 7.656 & 8 & .468 \\
\hline
\end{tabular}

Sumber: Data diolah

\section{Pengujian Koefisien Determinasi}

Dari pengujian ini nilai Cox \& Snell R Squarey yaitu 0,09 dan nilai Nagelkerke $\mathrm{R}$ Square adalah 0,154 yang bermakna bahwa $15,4 \%$ variabel dependen dapat dijelaskan oleh variabel independen yang ditampilkan pada tabel 4.4.

Tabel 4.4

Nilai Cox and Snell $R$ Square dan Nagelkerke $R$ Square

\begin{tabular}{|c|c|c|c|}
\hline Step & $\begin{array}{c}-2 \text { Log } \\
\text { likelihood }\end{array}$ & $\begin{array}{c}\text { Cox \& Snell R } \\
\text { Square }\end{array}$ & $\begin{array}{c}\text { Nagelkerke } R \\
\text { Square }\end{array}$ \\
\hline 1 & $118.271^{\mathrm{a}}$ & .090 & .154 \\
\hline
\end{tabular}

Sumber: Data diolah

\section{Pengujian Hipotesis}

Berdasarkan uji keputusan regresi logistik, jika nilai signifikan $\leq 0,05$ maka variabel independen memiliki pengaruh terhadap variabel dependen. Hasil pengujian ditunjukan pada tabel 4.5 .

Tabel 4.5

Pengujian Hipotesis

\begin{tabular}{|l|c|c|c|}
\hline \multicolumn{1}{|c|}{ Variabel } & B & S.E. & Sig \\
\hline $\begin{array}{l}\text { Step } 1^{\text {a }} \text { Kemandirian } \\
\text { Daerah }\end{array}$ & 5.611 & 2.457 & .023 \\
\hline Kinerja Pemerintah & 10.140 & 5.097 & .047 \\
\hline SPI & -.896 & 1.393 & .520 \\
\hline Constant & .105 & 1.525 & .945 \\
\hline
\end{tabular}

Sumber: Data diolah

Pada tabel 4.5 menunjukan nilai signifikan setiap variabel independen yang dapat menentukan hipotesis diterima atau ditolak. Berdasarkan hasil tersebut maka persamaan regresi logistik untuk mengetahui pengaruh kemandirian daerah, kinerja pemerintah dan sistem pengendalian intern terhadap akuntabilitas pelaporan keuangan adalah:

$\operatorname{Ln} \frac{\mathrm{AP}}{1-\mathrm{AP}}=\alpha 0+\beta_{1} \mathrm{KD}+\beta_{2} \mathrm{KP}+\beta_{3} \mathrm{SP}+\mathrm{e}$

Ket:

AP $=$ Akuntabilitas Pelaporan

$\mathrm{KD}=$ Kemandirian Daerah

$\mathrm{KP} \quad=$ Kinerja Pemerintah

$\mathrm{SP}=$ Sistem Pengendalian Intern

Dari persamaan ini dapat di intepretasikan pengaruh variabel independen terhadap variabel dependen.

a. Variabel kemandirian daerah memiliki nilai koefisien regresi (B) 5,611 dengan nilai signifikan $0,023(<0,05)$, nilai koefisien positif memberi makna bahwa kemandirian daerah memiliki hubungan yang searah dengan akuntabilitas pelaporan yang berarti jika kemandirian daerah tinggi maka akuntabilitas 


\section{Jurnal Akuntansi dan Pajak, 21 (01), 2020, 192}

pelaporan keuangan akan meningkat. Nilai signifikan $<0,05$ menunjukan hasil pengujian hipotesis yaitu kemandirian daerah memiliki pengaruh positif terhadap akuntabilitas pelaporan keuangan, sehingga hipotesis pertama yaitu kemandiriaan daerah berpengaruh positif terhadap akuntabilitas pelaporan keuangan diterima.

b. Variabel kinerja pemerintah memiliki nilai koefisien regresi (B) 10,140 dengan nilai signifikan $0,047(<0,05)$, nilai koefisien positif memberi makna bahwa kinerja pemerintah memiliki hubungan yang searah dengan akuntabilitas pelaporan yang berarti semakin tinggi kinerja pemerintah maka akuntabilitas pelaporan keuangan semakin meningkat. Nilai signifikan $<0,05$ menunjukan hasil pengujian hipotesis yaitu kinerja pemerintah berpengaruh terhadap akuntabilitas pelaporan keuangan, sehingga hipotesis kedua yaitu kinerja pemerintah berpengaruh positif terhadap akuntabilitas pelaporan keuangan diterima.

c. Variabel sistem pengendalian intern memiliki nilai koefisien regresi (B) $-0,896$ dengan nilai signifikan $0,520(>0,05)$, nilai koefieisn negatif memberi makna bahwa sistem pengendalian intern memiliki hubungan yang berlawanan dengan akuntabilitas pelaporan. Nilai signifikan $>0,05$ menunjukan hasil bahwa sistem pengendalian intern tidak berpengaruh terhadap akuntabilitas pelaporan keuangan, sehingga hipotesis ketiga yaitu sistem pengendalian intern berpengaruh positif terhadap akuntabilitas pelaporan keuangan ditolak.

\section{KESIMPULAN}

Penelitian ini memberikan kesimpulan bahwa semakin tinggi kemandirian suatu daerah maka akuntabilitas pelaporan keuangan semakin meningkat. Jika pemerintah daerah secara mandiri mampu melakukan pembangunan daerah dengan berbagai kegiatan untuk kepentingan publik yang manfaatnya dapat dirasakan oleh masyarakat sehingga mendapatkan kepercayaan dari publik bahwa informasi keuangan yang disampaikan adalah informasi yang jelas dan akurat sesuai dengan harapan publik sehingga tanggung jawab pemda untuk melaporkan informasi penggunaan dana dalam laporan keuangan kepada publik semakin besar dan pemerintah daerah tidak menikmati otonomi tanpa batas untuk menyalahgunakan keuangan publik sehingga tujuan otonomi daerah tercapai. Semakin baik kinerja pemerintah maka akuntabilitas pelaporan keuangan semakin meningkat karena kinerja pemerintah yang baik akan memberikan kepercayaan kepada masyarakat sehingga pemerintah daerah mendapatkan dukungan dan kepercayaan dalam pengelolaan keuangan bahwa pemda menggunakan kekuasaan publik untuk membenarkan semua aktivitas publik yang dikelola oleh pemda untuk membangun daerah yang sesuai dengan harapan publik. Kejelasan dan kebenaran informasi mengenai aktivitas pemerintah melalui laporan keuangan menunjukan bahwa dengan kinerja yang baik, pemerintah daerah mampu meningkatkan akuntabilitas pelaporan keuangan untuk mencapai tujuan otonomi daerah. Sistem pengendalian intern tidak berpengaruh terhadap akuntabilitas pelaporan keuangan karena sistem pengendalian intern hanya tanggung jawab yang dijalankan pemda untuk pelaporan kepada pusat, sehingga tidak memenuhi tujuan akuntabilitas yaitu mendapatkan kepercayaan dari publik. Ada atau tidaknya pengendalian tetap akan terjadi penyalahgunaan keuangan publik jika pejabat yang berwenang memiliki dorongan untuk melakukan penyalahgunaan wewenang, sehingga publik tidak akan percaya bahwa laporan keuangan yang diterbitkan adalah akuntabel. Saran yang dapat diberikan dalam penelitian ini adalah perluas penelitian dengan menggunakan variabel independen yang berbeda seperti politik dinasti, teknologi informasi dan lain sebagainya dan pengukuran variabel SPI dan akuntabilitas pelaporan dapat menggunakan data primer berupa kuesioner.

\section{REFERENSI}

Afriyanti, D., H. G. Sabanu, dan F. Noor, 2015, Penilaian Indeks Akuntabilitas Instansi Pemerintah, Jurnal Tata Kelola dan Akuntabilitas Keuangan Negara, Vol. 1, No.1, Juli: 21-42.

Aman, A., T. A. Al-Shbail., dan Z. Mohammed, 2013, Enhacing Public Organization Accountability through E-Goverment System, International Journal of Conception on Management and Social Sciences, Vol. 1, No.1, Desember: 2357-2787. 


\section{Jurnal Akuntansi dan Pajak, 21 (01), 2020, 193}

Asfiryati, D., 2017, Pengaruh Penerapan Sistem Akuntansi Keuangan Daerah dan Penyajian Laporan Keuangan Terhadap Akuntabilitas Pengelolaan Keuangan Daerah Dengan Sistem Pengendalian Intern Sebagai Variabel Intervening, Jurnal Online Mahasiswa Fakultas Ekonomi, Vol. 4, No. 1, Februari: 1986-1999.

Badan Pemeriksa Keuangan Republik Indonesia, 2018, Pentingnya Tindak Lanjut Rekomendasi Hasil Pemeriksaan BPK (https://www.bpk.go.id, diunduh 17 Februari 2020).

Bastian, I., 2006, Akuntansi Pendidikan, Jakarta: Erlangga.

Erryana, V., dan H. Setyawan, 2016, Determinan Akuntabilitas Pelaporan Keuangan Pemerintah Daerah, Jurnal Akuntansi Indonesia, Vol. 5, No. 1, Januari: 1-14.

Essing, A. S., D. Saerang., dan L. Lambey, 2017, Analisis Pelaksanaan Tindak Lanjut Hasil Pemeriksaan BPK RI atas Laporan Keuangan Pemerintah Daerah di Kabupaten Kepulauan Talaud , Jurnal Riset Akuntansi dan Auditing, Vol. 8, No. 1, Juni: 118-128.

Fontanella, R., dan H. Rossieta, 2014, Pengaruh Desentralisasi Fiskal Dan Kinerja Terhadap Akuntabilitas Pelaporan Keuangan Pemerintah Daerah Di Indonesia, Simposium Nasional Akuntansi XVII.

Ghozali, I., 2018, Aplikasi Analisis Multivariate Dengan Program IBM SPSS 25, $9^{\text {th }}$ ed, Semarang: Badan Penerbit Universitas Diponegoro.

Hadi, W., 2017, Pengaruh Earning Performance Dan Proporsi PAD LKPD 2015 Terhadap Kemandirian Daerah Di Jawa Tengah, Jurnal Tata Kelola dan Akuntabilitas Keuangan Negara, Vol. 3, No.1, Juli: 1-19.

Halim, A., 2007, Akuntansi Sektor Publik Akuntansi Keuangan Daerah, $3^{\text {th }}$ ed, Jakarta: Salemba Empat.

Ikhtisar Hasil Pemeriksaan Semester 1 Badan Pemeriksa Keuangan (BPK) Republik Indonesia Tahun 2019.

Irmawati, F. D., dan S. Pratolo, 2016, Pengaruh Kinerja Keuangan, Politik Dinasti, dan Kinerja Pemerintah Daerah Terhadap Akuntabilitas Pelaporan Keuangan Pemerintah Daerah Di Indonesia Tahun 2012-2013, Jurnal Accounting Departement UMY (https://repository.umy.ac.id/handle/123456789/ 2756, diunduh 23 Januari 2020).
Lazyra, K. S., 2016, Analisis Rasio Keuangan Daerah Dalam Menilai Kinerja Keuangan Pemerintah Kota Medan, [Skripsi], Medan: Universitas Muhammadiyah Sumatera Utara.

Mudhofar, K., dan A. Tahar, 2016, Pengaruh Desentralisasi Fiskal dan Kinerja Terhadap Akuntabilitas Pelaporan Keuangan Pemerintah Daerah di Indonesia: Efek Moderasi dari Kinerja, Jurnal Akuntansi dan Investasi, Vol. 17, No. 2, Juli: 176-185.

Nogueira, S. P., dan Jorge, S. M., 2017, The Perceived Usefulness Of Financial Information For Decision-Making In Portuguese Municipalities: The Importance Of Internal Control, Journal of Applied Accounting Research, Vol 18, No. 1, Februari: 116-136

Peraturan Pemerintah No. 60 Tahun 2008 Tentang Sistem Pengendal ian Intern Pemerintah

Peraturan Pemerintah No. 71 Tahun 2010 Tentang Standar Akuntansi Pemerintah.

Pratiwi, R., dan Y. A. Aryani, 2016, Pengaruh Karakteristik Pemerintah Daerah, Kepala Daerah, Tindak Lanjut Temuan Audit Terhadap Opini, Jurnal Akuntansi, Vol. 20, No. 2, Mei: 167-189.

Purbasari, H., dan A. Bawono, 2017, Pengaruh Desentralisasi Fiskal, Sistem Pengendalian Internal Dan Kinerja Pemerintah Daerah Terhadap Akuntabilitas Laporan Keuangan, Jurnal Riset Akuntansi dan Keuangan Indonesia, Vol. 2, No. 2, September: 102-108.

Safitri, L. N., dan Darsono, 2015, Pengaruh Sistem Pengendalian Internal dan Temuan Kepatuhan Terhadap Opini Audit Pada Pemerintah Daerah, Diponegoro Journal Of Accounting, Vol. 5, No. 1, Januari: 1-12.

Santoso, B. E., 2016, Pengaruh Sistem Pengendalian Intern Pemerintah, Pemanfaatn Teknologi Informasi Dan Kompetensi Sumber Daya Manusia Terhadap Akuntabilitas Keuangan Daerah, [Tesis], Lampung: Universitas Lampung.

Suryanto, 2017, Akuntabilitas Pelaporan Keuangan Pemerintah Daerah Di Indonesia, Jurnal Agregasi, Vol. 5, No. 1, Mei: 72-91.

Wicaksono, W. K., 2015, Akuntabilitas Organisasi Sektor Publik, Jurnal Kebijakan dan Administrasi Publik, Vol. 19, No. 1, Mei: 3-15. 